\title{
An investigation into the effects of hemodynamic changes on the patient's clinical condition during the treatment of patients undergoing aneurysmal subarachnoid hemorrhage
}

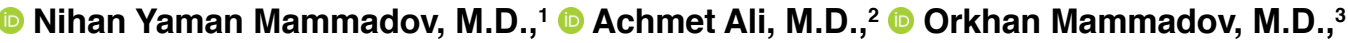 \\ 당 Ararso Kedir Jima, M.D., ${ }^{3}$ 이 Günseli Orhun, M.D., ${ }^{2} \odot$ İbrahim Özkan Akıncı, M.D. ${ }^{4}$
}

\author{
1Department of Anesthesiology, University of Health Sciences, Van Training and Research Hospital, Van-Turkey \\ ${ }^{2}$ Department of Anesthesiology, İstanbul University İstanbul Faculty of Medicine, İstanbul-Turkey \\ ${ }^{3}$ Department of Intensive Care Unit, Altunizade Acıbadem Hospital, İstanbul-Turkey \\ ${ }^{4}$ Department of Intensive Care Unit, Taksim Acıbadem Hospital, İstanbul-Turkey
}

\begin{abstract}
BACKGROUND: In this study, we investigated the hemodynamic changes in patients with aneurysmal subarachnoid hemorrhage $(\mathrm{aSAH})$ during the intensive care unit and the effects of $\mathrm{PiCCO}$ on the hemodynamic clinical course during hydration and hypertension treatment.

METHODS: In our study, 15 adult aSAH patients, whose aneurysm had been treated by surgery or coiling, were examined for the signs of vasospasm in between the dates 03/0I/20I5 and 0I/03/2016. The PICCO measurement was made at least twice in a day. Positive daily fluid balance was attempted to be at least $1000 \mathrm{~mL}$ and the value of the Global end-diastolic index (GEDI) was targeted to 680 to $800 \mathrm{~mL} / \mathrm{m}^{2}$ for each patient. The values of mean arterial pressure (MAP), systolic arterial pressure (SAP), heart rate (HR), central venous pressure (CVP), and cardiac index (CI), GEDI, systemic vascular resistance index (SVRI), extravascular lung water index (ELWI) measured by PiCCO, and daily neurological outcome of patients and GCS values were recorded.

RESULTS: It had been observed that CVP value was randomly changing during the volume therapy, but the GEDI value determined by thermodilution was consistent. A positive correlation was detected between the period of reaching the hospital and the first measured value of SVRI. Low GEDI value was detected as a risk factor in the perspective of vasospasm, but an ideal GEDI value could not be determined.
\end{abstract}

CONCLUSION: GEDI values were correlated with daily fluid balance. While low GEDI value was found as a risk factor, we could not determine an ideal GEDI value.

Keywords: Fluid therapy; PiCCO; subarachnoid hemorrhage; vasospasm.

\section{INTRODUCTION}

The most common complication of aneurysmal subarachnoid hemorrhage $(\mathrm{aSAH})$ concerning mortality and morbidity is the development of delayed cerebral ischemia $(\mathrm{DCl})$ due to cerebral vasospasm. Cerebral vasospasm is reported to be observed in $16-71 \%$ according to its definition. ${ }^{[1,2]}$ The main cause of mortality and morbidity associated with ischemic deficits, such as changes in consciousness and motor neurological losses, is defined as clinical vasospasm and occurs only in $17-21 \%$ of all aSAH patients. ${ }^{[1,3]}$

Although prophylactic triple-H therapy (hypervolemia, hypertension, hemodilution) for preventing delayed cere-

\footnotetext{
Cite this article as: Yaman Mammadov N, Ali A, Mammadov O, Jima AK, Orhun G, Akıncı İÖ. An investigation into the effects of hemodynamic changes on the patient's clinical condition during the treatment of patients undergoing aneurysmal subarachnoid hemorrhage. Ulus Travma Acil Cerrahi Derg 2020;26:563-567.

Address for correspondence: Nihan Yaman Mammadov, M.D.

Sağılık Bilimleri Üniversitesi Van Eğitim ve Araştırma Hastanesi, Anesteziyoloji ve Reanimasyon Kliniği, Van, Turkey

Tel: +904449965 E-mail: nihanyaman87@gmail.com

Ulus Travma Acil Cerrahi Derg 2020;26(4):563-567 DOI: 10.14744/tjtes.2020.244I2 Submitted: 29.09.2019 Accepted: I4.01.2020 Online: I5.06.2020 Copyright 2020 Turkish Association of Trauma and Emergency Surgery
} 
bral ischemia was acceptable, current evidence does not support its efficacy and recommends maintaining normovolemia. ${ }^{[4]}$ Induced hypertension and volume status have been regarded as important, but heart failure and pulmonary edema are the most important complications of this therapy. ${ }^{[5,6]}$ Although blood pressure is a treatment goal for cerebral perfusion, monitoring cardiac output (CO) and stroke volume variation (SVV) are important for adequate treatment. ${ }^{[7]}$

PiCCO, which is the transpulmonary thermodilution method, enables assessment of the patient's hemodynamic status to guide fluid or vasoactive drug therapy. In recent years, it has been shown that the usage of PiCCO may be useful in the follow-up of SAH patients. ${ }^{[8]}$

In this study, we aimed to evaluate physiological monitoring values for $\mathrm{PiCCO}$ in aSAH patients during hydration and hypertension $(2 \mathrm{H})$ treatment for the continuation of euvolemia.

\section{MATERIALS AND METHODS}

In this study, we included 15 adults, aSAH patients with aneurysm who were undergone to surgical clips or angiographic coils that were hospitalized between 0I.03.20I5 and 01.03.2016. Patients who did not want to participate in this study and who did not apply to our hospital despite the development of aSAH on the first three days and the patients who were admitted to our Intensive Care Unit with a poor neurological score of age < 18 [World Federation of Neurosurgeons Score (WFNS): 5 and low Glasgow Coma Score (GCS) <4], incidental aneurysms and patients whose aneurysm could not be closed by surgical or endovascular methods were excluded from this study. A femoral PiCCO artery catheter and a subclavian CVP catheter were inserted to the patients, and $\mathrm{PiCCO}$ measurement was performed at least twice a day, morning and evening.

The insensible fluid losses of the patients were considered to be $400-600 \mathrm{~mL}$ and the daily fluid balance was planned to be approximately $1000 \mathrm{~mL}$ positivity to achieve isovolemia and the global end-diastolic index (GEDI) value measured by $\mathrm{PiCCO}$ was targeted to be the normal range of 680 $800 \mathrm{~mL} / \mathrm{m}^{2}$. Mean arterial pressure (MAP), systolic arterial pressure (SAP), heart rate (HR), central venous pressure (CVP) and cardiac index (Cl), GEDI, systemic vascular resistance index (SVRI), extravascular lung water index (ELWI) measured by $\mathrm{PiCCO}$ were recorded. In addition, patients' Fisher score, ${ }^{[9]}$ Hunt-Hess score, ${ }^{[10]}$ and daily neurological examination results were recorded as GCS values. In addition, after additional fluid replacement and/or hemodynamic support, PiCCO measurements were repeated to evaluate the effects of $\mathrm{Cl}$, GEDI and/or SVV measurements on the improvement of clinical vasospasm findings. Intensive care and hospital stay, Glasgow outcome scores and morbidity were recorded.
Table I. Demographic and descriptive characteristics

\begin{tabular}{lc}
\hline Gender (male/female) & $9 / 6$ \\
Age (year) & $47.9 \pm 10.2$ \\
Height & $166.0 \pm 10.3$ \\
Weight & $80.1 \pm 9.2$ \\
Location of aneurysm & \\
$\quad$ Anterior communicant artery & 4 \\
$\quad$ Posterior communicant artery & 5 \\
$\quad$ Middle cerebral artery & 4 \\
$\quad$ Carotid artery & 2 \\
GCS on admission & $12.5 \pm 2.1$ \\
WFNS (I/II/III/IV/V) & $1 / 5 / 5 / 3 / I$ \\
Hunt and Hess score (I /II/III/IV) & $0 / 5 / 8 / 2$ \\
Fisher score (I/II/III/IV) & $0 / 5 / 6 / 4$ \\
Hospital admission day & $2.6 \pm I .7$ \\
\hline GCS. Giasgow Coma Score:WFNS:World Federation of Neurosurgeons Score.
\end{tabular}

GCS: Glasgow Coma Score; WFNS: World Federation of Neurosurgeons Score.

Clinical vasospasm findings: Minor findings; headache, agitation, leukocytosis (non-infectious), unconsciousness and disorientation; major findings were; decrease in GCS (>2), new motor deficit and/or aphasia and/or dysphasia were accepted as newly developing visual defects.

Quantitative data were expressed as mean and standard deviation, and qualitative data were expressed as number and percentage of cases. Pearson correlation analysis was used to correlate the quantitative data. Correlation levels were defined as $r \leq 0.3$ low, $0.3<r<0.5$ medium and $r \geq 0.5$ advanced. SPSS 15.0 program was used for statistical analysis of data and graphs.

\section{RESULTS}

In total, 15 patients completed this study (Fig. I). The distribution of the aneurysm concerning location is shown in Table I. The average GCS mean of patients was $12.5 \pm 2$.I days and on hospitalization day after bleeding average was $2.6 \pm \mathrm{I} .7$ days (Table I). It was observed that $\mathrm{Cl}$ values were statistically higher on the $4^{\text {th }}$ day, $6^{\text {th }}$ day, $8^{\text {th }}$ day, $10^{\text {th }}$ day, $12^{\text {th }}$ day than the first days (Fig. 2). In the follow-up of the fluid treatment

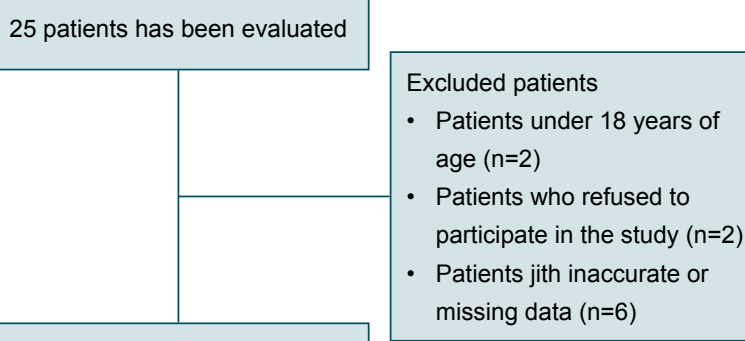

25 patients completed the study

Figure 1. Working flow chart. 
during intensive care follow-ups, it was observed that CVP values were not appropriate and CVP values were changed inappropriately and randomly during the treatment process However, GEDI value determined by thermodilution showed a consistent course with the fluid amount given and daily balance of the patient (Figs. 3, 4). In addition, it was figured out that the data measured by thermodilution were more objective than central venous pressure in the management of fluid therapy. Significant correlation between hospitalization time and the first measured SVRI value was observed (Fig. 5). This correlation was thought to be related to the attempt to achieve cardiac output by increasing systemic vascular resistance in SAH patients who did not receive adequate fluid therapy. Low GEDI was found to be a risk factor for vasospasm development (Fig. 6).

In our study, no ideal GEDI value could be determined although there was a negative correlation between the number of days with vasospasm symptoms and the GEDI value.

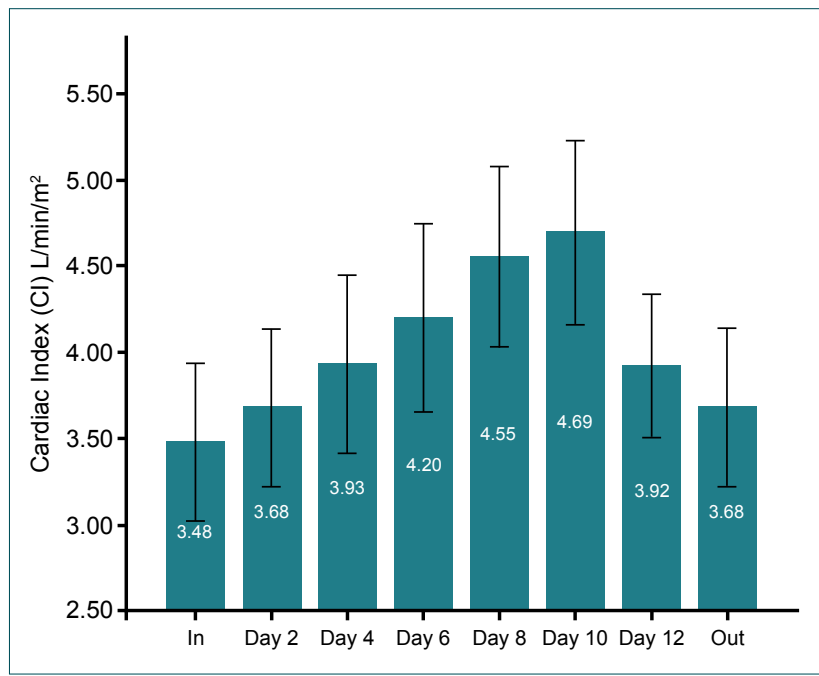

Figure 2. Cardiac index data.

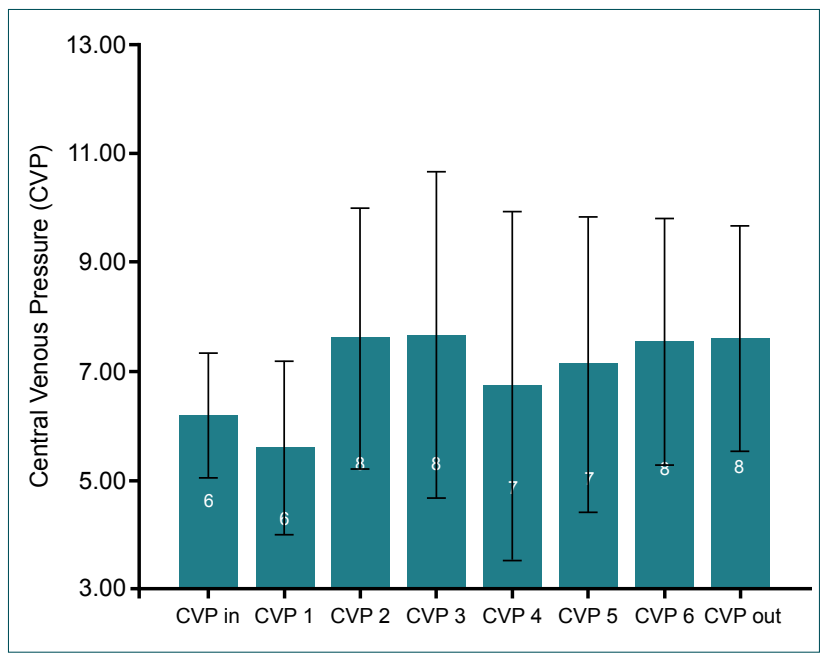

Figure 3. Mean values of central venous pressure measurements according to follow-up days.

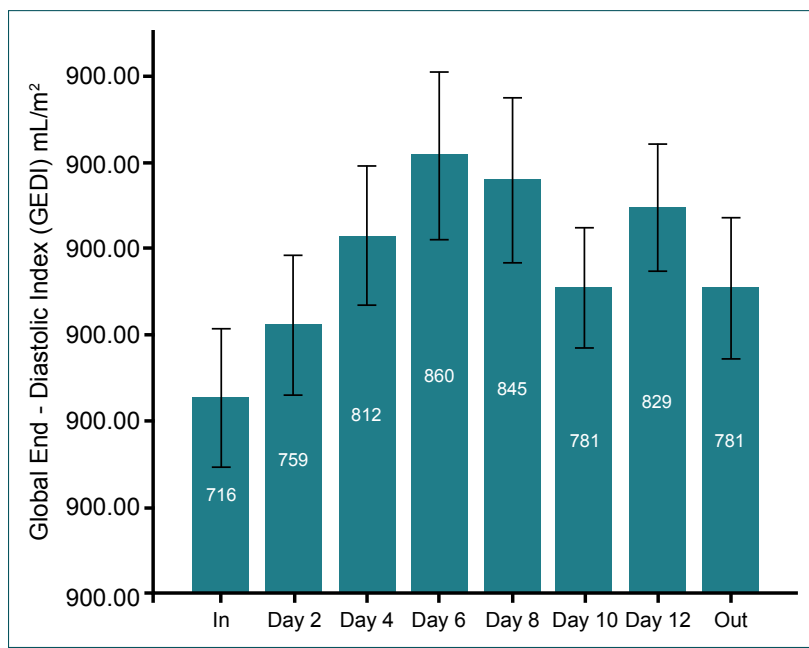

Figure 4. Global end diastolic index (GEDI) data.

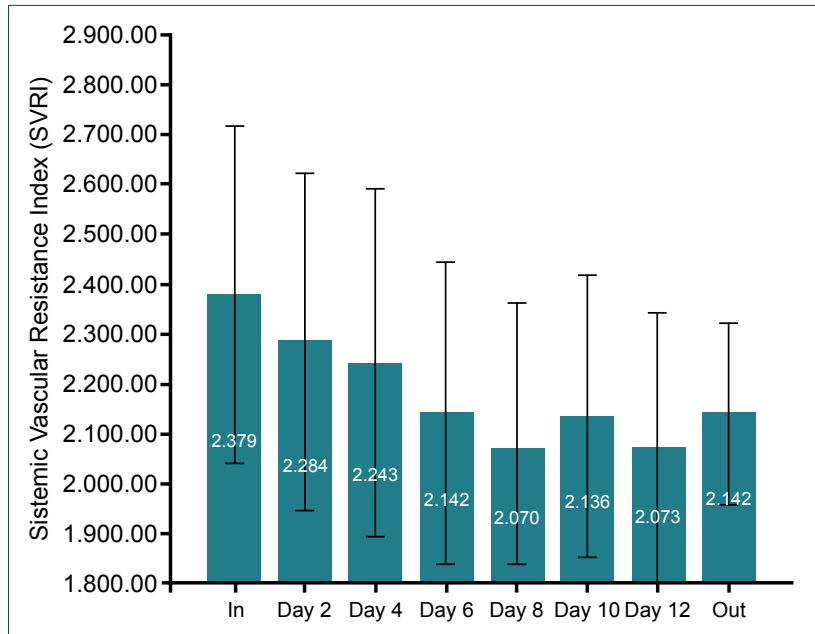

Figure 5. Systemic vascular resistance index (SVRI) data.

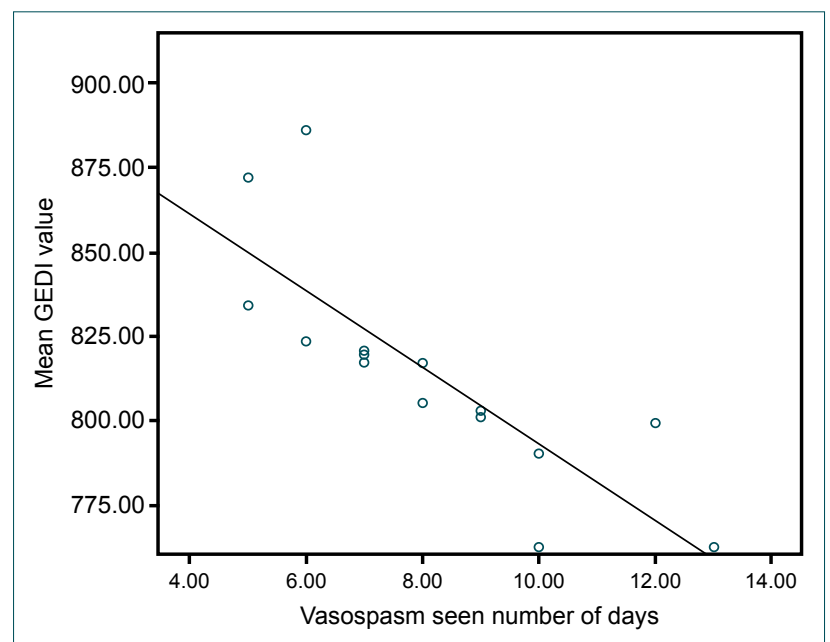

Figure 6. Number of days with vasospasm and mean global end diastolic index (GEDI) correlation curve.

\section{DISCUSSION}

In our study, a high correlation was found between the first day of hospitalization and the first measured SVRI value after 
bleeding in aSAH patients, and low GEDI value was found to be a risk factor for the development of vasospasm. In addition, it was found that the data measured by thermodilution were more objective than CVP in the management of fluid therapy. In addition to neurological symptoms after aSAH, cardiac and pulmonary effects are seen as a result of sympathetic activation and parasympathetic dysfunction due to secreted neuromediators after injury. ${ }^{[1,12]}$ Following the clinical development of $\mathrm{SAH}$, in patients, increased reflex sympathetic stimulation with QT prolongation in ECG and arrhythmias were seen; concerning hemodynamic, as observed in our study, to ensure cerebral perfusion, hypertension was detected; and decrease in $\mathrm{Cl}$ and increase in SVRI is also observed. ${ }^{[13,14]}$ Studies have shown that there is a correlation between the severity of bleeding and cardiac complications and that cardiac dysfunction is respectively more serious after severe bleeding. ${ }^{[15]}$ Although there are negative studies regarding the effectiveness of $2 \mathrm{H}$ all over the world, in some centers, this method $(2 \mathrm{H})$ is used in the treatment of vasospasm after SAH. ${ }^{[16-18]}$ Hypertension and hypervolemia are the two treatments responding to $2 \mathrm{H}$. To overcome the vasospasm after aSAH, while maintaining the intravascular volume, it is necessary to increase $\mathrm{Cl}$ and simultaneously increase cerebral blood flow. This is the basic physiological logic of $2 \mathrm{H}$ treatment in aSAH treatment. In a randomized study of 82 patients with SAH, Lennihan et al. ${ }^{[16]}$ showed that the risk of hypotension during intensive care treatment was lower in the group of patients who underwent hypervolemia and consequently, $\mathrm{DCl}$ was observed less. Mortality and morbidity were better in the hypervolemia group, although there was no statistical difference. However, in recent studies, a positive fluid balance was found to be associated with poor outcomes in patients diagnosed with aSAH, ${ }^{[19]}$ and prophylactic hypervolemia was not found to reduce the risk of late cerebral ischemia, ${ }^{[16]}$ the fluid limitation has been experienced to be harmful. ${ }^{[19,20]}$ In the method of our study, we took the patient's involuntary losses (Perspiratio Insensibilis) as the physiological value of $450-500 \mathrm{~mL}$, and we gave another 500 $\mathrm{mL}$ of fluid to compensate for the additional losses that arise from samples taken for laboratory tests, lumbar puncture and fever. Furthermore, we aimed to keep the volume balance close to the upper limits of isovolemia by avoiding involuntary hypovolemia with an average of $100 \mathrm{~mL}$ positive fluid balance. With this fluid treatment approach, we achieved our goal in all patients, as demonstrated by the results of $\mathrm{PiCCO}$ measurements. Studies have shown that PiCCO-administered fluid therapy would be more appropriate for the treatment of vasospasm. ${ }^{[8]}$ According to Mutoh et al., ${ }^{[7]}$ the value of the GEDI measured by thermodilution method was described the volume status of patients significantly higher sensitivity and specificity compared to CVP value and in the PiCCO group of patients, vasospasm symptoms and $\mathrm{DCl}$ were determined less frequently compared to the traditional follow-up group. In addition, it was figured out that pulmonary complications were less experienced in the PiCCO group. In this study, we kept track of aSAH patients with the data obtained using thermodilution method. In the fluid treatment during intensive care follow-up, we found that the CVP value was inappropriate and the CVP values changed during the treatment period in an inappropriate and random manner. The GEDI value determined by thermodilution was consistent with the amount of fluid administered and the daily balance of the patient.

Similar to our study, other studies in the literature recommend the use of hemodynamic parameters obtained from thermodilution measurements performed with $\mathrm{PiCCO}$ to optimize fluid balance and prevent pulmonary complications in the follow-up of aSAH patients. ${ }^{[7,8,14]}$ In our study, we also found that in patients with increased volume equilibrium with fluid therapy, the measured SVRI value decreased over time. Although previous studies have shown that low $\mathrm{Cl}$ and GEDI values have negative effects on mortality and morbidity, no ideal GEDI value to be recommended in patient follow-up has been defined..$^{[5,14,21]}$ The GEDI value (normal range 680-800 $\mathrm{mL} / \mathrm{m}^{2}$ ) was associated with both pulmonary edema (>921 $\left.\mathrm{mL} / \mathrm{m}^{2}\right)$ and $\mathrm{DCl}\left(<822 \mathrm{~mL} / \mathrm{m}^{2}\right)$ in a study conducted in $2014 .^{[5]}$

In our study, we found a negative correlation between the number of days with vasospasm symptoms and GEDI value and found that low GEDI value was an important risk factor for the development of clinical vasospasm. However, as a result of our study, we could not reach the cut-off value of the SVRI and GEDI values in the treatment of vasospasm. The most important reason for this is that we have not reached the number of patients required to reach this result, which is the most important limitation of our study.

\section{Conclusion}

The results of the present study show that $\mathrm{PiCCO}$-guided hemodynamic management helps to optimize fluid input and balance without negatively impacting on preload parameters and GCS. However, we need multicentre studies with large patient groups to obtain more accurate results.

Ethics Committee Approval: Approved by the local ethics committee.

Peer-review: Internally peer-reviewed.

Authorship Contributions: Concept: N.Y.M., I.Ö.A.; Design: N.Y.M., I.Ö.A.; Supervision: A.A., I.Ö.A. Fundings: N.Y.M., I.Ö.A.; Materials: O.M., A.K.J., G.O.; Data: O.M., A.K.J., G.O.; Analysis: A.A., G.O., O.M.; Literature search: N.Y.M., I.Ö.A.; Writing: N.Y.M., O.M., I.Ö.A.; Critical revision: O.M., I.Ö.A., N.Y.M.

Conflict of Interest: None declared.

Financial Disclosure: The authors declared that this study has received no financial support.

\section{REFERENCES}

1. Frontera JA, Fernandez A, Schmidt JM, Claassen J, Wartenberg KE, Badjatia N, et al. Defining vasospasm after subarachnoid hemorrhage: what is the most clinically relevant definition? Stroke 2009;40:1963-8.

2. Dupont SA, Wijdicks EF, Manno EM, Lanzino G, Rabinstein AA. Predic- 
tion of angiographic vasospasm after aneurysmal subarachnoid hemorrhage: value of the Hijdra sum scoring system. Neurocrit Care 2009;11:172-6.

3. Frontera JA, Claassen J, Schmidt JM, Wartenberg KE, Temes R, Connolly ES Jr, et al. Prediction of symptomatic vasospasm after subarachnoid hemorrhage: the modified fisher scale. Neurosurgery 2006;59:21-7.

4. Kurtz P, Helbok R, Ko SB, Claassen J, Schmidt JM, Fernandez L, et al. Fluid responsiveness and brain tissue oxygen augmentation after subarachnoid hemorrhage. Neurocrit Care 2014;20:247-54. [CrossRef]

5. Tagami T, Kuwamoto K, Watanabe A, Unemoto K, Yokobori S, Matsumoto G, et al; SAH PiCCO Study Group. Optimal range of global end-diastolic volume for fluid management after aneurysmal subarachnoid hemorrhage: a multicenter prospective cohort study. Crit Care Med 2014;42:1348-56. [CrossRef]

6. Gonzalez J, Delafosse C, Fartoukh M, Capderou A, Straus C, Zelter M, et al. Comparison of bedside measurement of cardiac output with the thermodilution method and the Fick method in mechanically ventilated patients. Crit Care 2003;7:171-8. [CrossRef]

7. Mutoh T, Kazumata K, Ishikawa T, Terasaka S. Performance of bedside transpulmonary thermodilution monitoring for goal-directed hemodynamic management after subarachnoid hemorrhage. Stroke 2009;40:2368-74. [CrossRef]

8. Bajorat J, Hofmockel R, Vagts DA, Janda M, Pohl B, Beck C, et al. Comparison of invasive and less-invasive techniques of cardiac output measurement under different haemodynamic conditions in a pig model. Eur J Anaesthesiol 2006;23:23-30. [CrossRef]

9. Fisher CM, Kistler JP, Davis JM. Relation of cerebral vasospasm to subarachnoid hemorrhage visualized by computerized tomographic scanning. Neurosurgery 1980;6:1-9. [CrossRef]

10. Hunt WE, Hess RM. Surgical risk as related to time of intervention in the repair of intracranial aneurysms. J Neurosurg 1968;28:14-20. [CrossRef]

11. Jeon IC, Chang CH, Choi BY, Kim MS, Kim SW, Kim SH. Cardiac troponin I elevation in patients with aneurysmal subarachnoid hemorrhage. J Korean Neurosurg Soc 2009;46:99-102. [CrossRef]

12. Naidech AM, Kreiter KT, Janjua N, Ostapkovich ND, Parra A, Com- michau C,et al. Cardiac troponin elevation, cardiovascular morbidity, and outcome after subarachnoid hemorrhage. Circulation 2005;112:2851-6.

13. van der Bilt IA, Hasan D, Vandertop WP, Wilde AA, Algra A, Visser FC, et al. Impact of cardiac complications on outcome after aneurysmal subarachnoid hemorrhage: a meta-analysis. Neurology 2009;72:635-42.

14. Yoneda H, Nakamura T, Shirao S, Tanaka N, Ishihara H, Suehiro E, et al; SAH PiCCO Study Group. Multicenter prospective cohort study on volume management after subarachnoid hemorrhage: hemodynamic changes according to severity of subarachnoid hemorrhage and cerebral vasospasm. Stroke 2013;44:2155-61. [CrossRef]

15. Mashaly HA, Provencio JJ. Inflammation as a link between brain injury and heart damage: the model of subarachnoid hemorrhage. Cleve Clin J Med 2008;75:S26-30. [CrossRef]

16. Lennihan L, Mayer SA, Fink ME, Beckford A, Paik MC, Zhang H, et al. Effect of hypervolemic therapy on cerebral blood flow after subarachnoid hemorrhage : a randomized controlled trial. Stroke 2000;31:383-91.

17. Keller TS, McGillicuddy JE, LaBond VA, Kindt GW. Modification of focal cerebral ischemia by cardiac output augmentation. J Surg Res 1985;39:420-32. [CrossRef]

18. Egge A, Waterloo K, Sjøholm H, Solberg T, Ingebrigtsen T, Romner B. Prophylactic hyperdynamic postoperative fluid therapy after aneurysmal subarachnoid hemorrhage: a clinical, prospective, randomized, controlled study. Neurosurgery 2001;49:593-606. [CrossRef]

19. Kissoon NR, Mandrekar JN, Fugate JE, Lanzino G, Wijdicks EFM, Rabinstein AA. Positive fluid balance is associated with poor outcomes in subarachnoid hemorrhage. J Stroke \& Cerebrovascular Diseases 2015;24:2245-51. [CrossRef]

20. Rosenwasser RH, Delgado TE, Buchheit WA, Freed MH. Control of hypertension and prophylaxis against vasospasm in cases of subarachnoid hemorrhage: a preliminary report. Neurosurgery 1983;12:658-61. [CrossRef]

21. Taccone FS, Citerio G; Participants in the International Multi-disciplinary Consensus Conference on Multimodality Monitoring. Advanced monitoring of systemic hemodynamics in critically ill patients with acute brain injury. Neurocrit Care 2014;21:S38-63. [CrossRef]

\section{ORIJINAL ÇALIŞMA - ÖZET}

\section{Anevrizmal subaraknoid kanama geçiren hastalarda tedavi süresince gelişen hemodinamik değişikliklerin kliniğe etkilerinin araştırılması \\ Dr. Nihan Yaman Mammadov, ${ }^{1}$ Dr. Achmet Ali, ${ }^{2}$ Dr. Orkhan Mammadov, ${ }^{3}$ Dr. Ararso Kedir Jima, ${ }^{3}$ Dr. Günseli Orhun, ${ }^{2}$ Dr. İbrahim Özkan Akıncı ${ }^{4}$}

${ }^{1}$ Sağılık Bilimleri Üniversitesi Van Eğitim ve Araştırma Hastanesi, Anesteziyoloji ve Reanimasyon Kliniği, Van ${ }^{2}$ Isstanbul Üniversitesi İstanbul Tıp Fakültesi, Anesteziyoloji Anabilim Dalı, İstanbul

${ }^{3}$ Altunizade Acıbadem Hastanesi, Genel Yoğun Bakım Kliniği, İstanbul

${ }^{4}$ Taksim Acıbadem Hastanesi, Genel Yoğun Bakım Kliniği, İstanbul

AMAÇ: Çalışmamızda anevrizmal subaraknoid kanama (aSAK) hastalarının yoğun bakım izlemlerinde hemodinamik değişiklikleri ve hidrasyon, hipertansiyon tedavisi sırasında PiCCO ile ölçülen hemodinamik parametrelerin klinik seyre etkisini inceledik.

GEREÇ VE YÖNTEM: Çalışmamızda 01.03.20I5 ve 0I.03.2016 tarihleri arasında cerrahi klip veya endovasküler koil ile anevrizması tedavi edilen, erişkin, 15 aSAK hastası vazospazm açısından incelendi. Günde en az iki kez PiCCO ölçümü yapıldı. Sıvı tedavisi günlük en az $1000 \mathrm{~mL}$ pozitiflik olacak şekilde, Global end-diyastolik İndeks (GEDi) değeri $680-800 \mathrm{~mL} / \mathrm{m}^{2}$ şeklinde hedeflendi. Hastaların geliş ortalama arter basıncı (OAB), sistolik arter basıncı (SAB), kalp atım hızı (KAH), santral venöz basınç (CVP) ve kardiyak indeks (CI), GEDI, sistemik vasküler rezistans indeksi (SVRI), ekstravasküler akciğer volüm indeksi (ELWI) değerleri kaydedildi. Hastaların günlük nörolojik muayeneleri, klinik vazospazm bulguları, GKS değerleri kaydedildi. BULGULAR: Hastaların volüm durumları ve volüm tedavisi takibinde CVP değerinin rastgele değiştiği fakat termodilüsyon ile saptanan GEDI değerinin uyumlu olduğu görüldü. Hastaneye geliş süresi ile ilk ölçülen SVRI değeri arasında ileri düzeyde pozitif korelasyon saptandı. Düşük GEDI değerinin vazospazm açısından risk faktörü olduğu bulundu.

TARTIŞMA: Volüm tedavisinin takibindeki değişikliklerle GEDI değerindeki değişikliklerin uyumlu olduğu görüldü. Düşük GEDI değerinin vazospazm açısından risk faktörü olduğu bulunmasına rağmen, önerilecek ideal bir GEDI değeri saptanamadı.

Anahtar sözcükler: PiCCO; sıvı tedavisi; subaraknoid kanama; vazospazm.

Ulus Travma Acil Cerrahi Derg 2020;26(4):563-567 doi: 10.14744/tjtes.2020.24412 